\title{
A deep-sea hydrothermal vent community dominated by Stauromedusae
}

\author{
Richard A. Lutz ${ }^{\mathrm{a}, *}$, Daniel Desbruyères ${ }^{\mathrm{b}}$, Timothy M. Shank ${ }^{\mathrm{a}}$, \\ Robert C. Vrijenhoek ${ }^{\mathrm{a}}$
}

'Department of Marine and Coastal Sciences, Rutgers University, New Brunswick, NJ 08903, USA

'Deep Sea Environment Department, IFREMER, Centre de Brest, B.P. 70, 29280 Plouzane, France

\begin{abstract}
A dense population of stauromedusan scyphozoans (morphologically similar to previously described species within the genus Lucernaria) was encountered in a previously undocumented area of hydrothermal activity along the crest of the East Pacific Rise (Lat. 20 50.304' N; Long. $10905.422^{\prime} \mathrm{W}$; depth of $2605 \mathrm{~m}$ ). A few galatheid (Munidopsis subsquamosa) and bythograeid (Bythograea thermydron) crabs and occasional anemones ( $C$ yananthe $a$ sp.) were the only other vent-associated megafauna observed within the region. This report represents: (1) the first documented occurrence of a biological community dominated by Stauromedusae at an active hydrothermal vent; (2) one of the deepest reported occurrences of Sta uromedusae in the world's oceans; and (3) documentation of the existence of a species within a class (Scyphozoa) of organisms that thus far has not been reported from hydrothermal vents or other reducing environments. 1998 Elsevier Science Ltd. All rights reserved.
\end{abstract}

\section{Introduction}

Since the discovery in 1977 of deep-sea hydrothermal vents, over 400 new species have been encountered in these unusual environments throughout the world's oceans (Grassle, 1986; Tunnicliffe, 1991; Desbruyeres et al., 1994; T. Wolff, personal communication). While the biomass and density of constituent organisms at any particular hydrothermal field are high, diversity is generally low, with a few megafaunal species dominating a single vent area. The dominant vent megafauna have included molluses (e.g. mytilid and vesicomyid bivalves, provannid gastropods), decapod crustaceans

\footnotetext{
${ }^{*}$ Corresponding author. Tel.: 001 7329328959; fax: 0017329326557 ; e-mail; rlutz@ahab.rutgers.edu.
} 
(e.g. bresiliid shrimp, bythograeid crabs), anthozoans, annelids (alvinellids), and vestimentiferans (Rona et al., 1986; Van Dover, 1990; Hessler and Lonsdale, 1991; Tunnicliffe, 1991; Lutz and Kennish, 1993; Desbruyeres et al., 1994). Herein, we offer the first account of a biological community dominated by stauromedusan scyphozoans at an active hydrothermal vent. Occurring at a depth of $2605 \mathrm{~m}$ along the East Pacific Rise, this discovery also represents one of the deepest reported occurrences of Stauromedusae and the first time a representative of the class Scyphozoa (Cnidaria) has been encountered in a hydrothermal vent (or any other reducing) environment.

Stauromedusae have a cosmopolitan distribution, but are most diverse and abundant in shallow, temperate waters of the Northern Hemisphere (Eckelbarger and Larson, 1993). Juvenile and adult stages are polyp-like and entirely sessile, with dispersal being restricted to an unciliated planula stage that creeps along the bottom with a vermiform type of locomotion (Thiel, 1966; Otto, 1976, 1978; Barnes, 1987). Sublittoral forms are frequently found attached to sea grass, algae or rocky substrata, and typically feed upon small crustaceans (Hyman, 1940; Eckelbarger and Larson, 1993). To date, there has been only one report of Stauromedusae in an abyssal habitat (Lucernaria bathyphila at a depth of $2800 \mathrm{~m}$ in the Northeast Atlantic) (Naumov, 1961).

\section{Materials and methods}

In June 1990 the submersible Alvin (Dive 2231) visited a previously undocumented area of hydrothermal activity along the crest of the East Pacific Rise approximately $20^{\circ} 50.304^{\prime} \mathrm{N}$ and $109^{\circ} 05.422^{\prime} \mathrm{W}$. External cameras mounted on the manipulator arm and sponson of the submersible were utilized to obtain detailed video (recorded on a standard $8 \mathrm{~mm}$ format) and $35 \mathrm{~mm}$ photographic images of the macrofauna in the vicinity of venting fluids associated with a hydrothermally active fissure within the area. Selected video images of Stauromedusae inhabiting the fissure were frame grabbed using Media Cybernetics Image-Pro Plus software and a Coreco OculusTCX/MX capture board in a Dell Optiplex XMT $120 \mathrm{MHz}$ Pentium computer, and printed using Adobe Photoshop software and a Fujix Pictography 3000 printer.

\section{Results and discussion}

Hydrothermal activity at the newly discovered vent site appeared to be restricted to a single small fissure (approximately $2 \mathrm{~m}$ in length) from which emanated a large

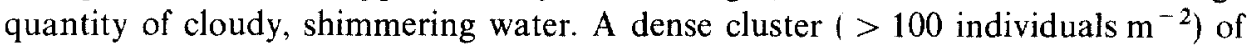
white, translucent stalked scyphozoans was observed within the fissure, and isolated organisms were present up to a distance of several meters from the opening (Fig. 1a). A size spectrum of animals was present, with maximum dimensions (proximal end of stalk to tip of tentacles) of individual organisms (discernible in video images) ranging from approximately $1-10 \mathrm{~cm}$ (Fig. 1 b) (it should be noted that $10 \mathrm{~cm}$ is an unusually 


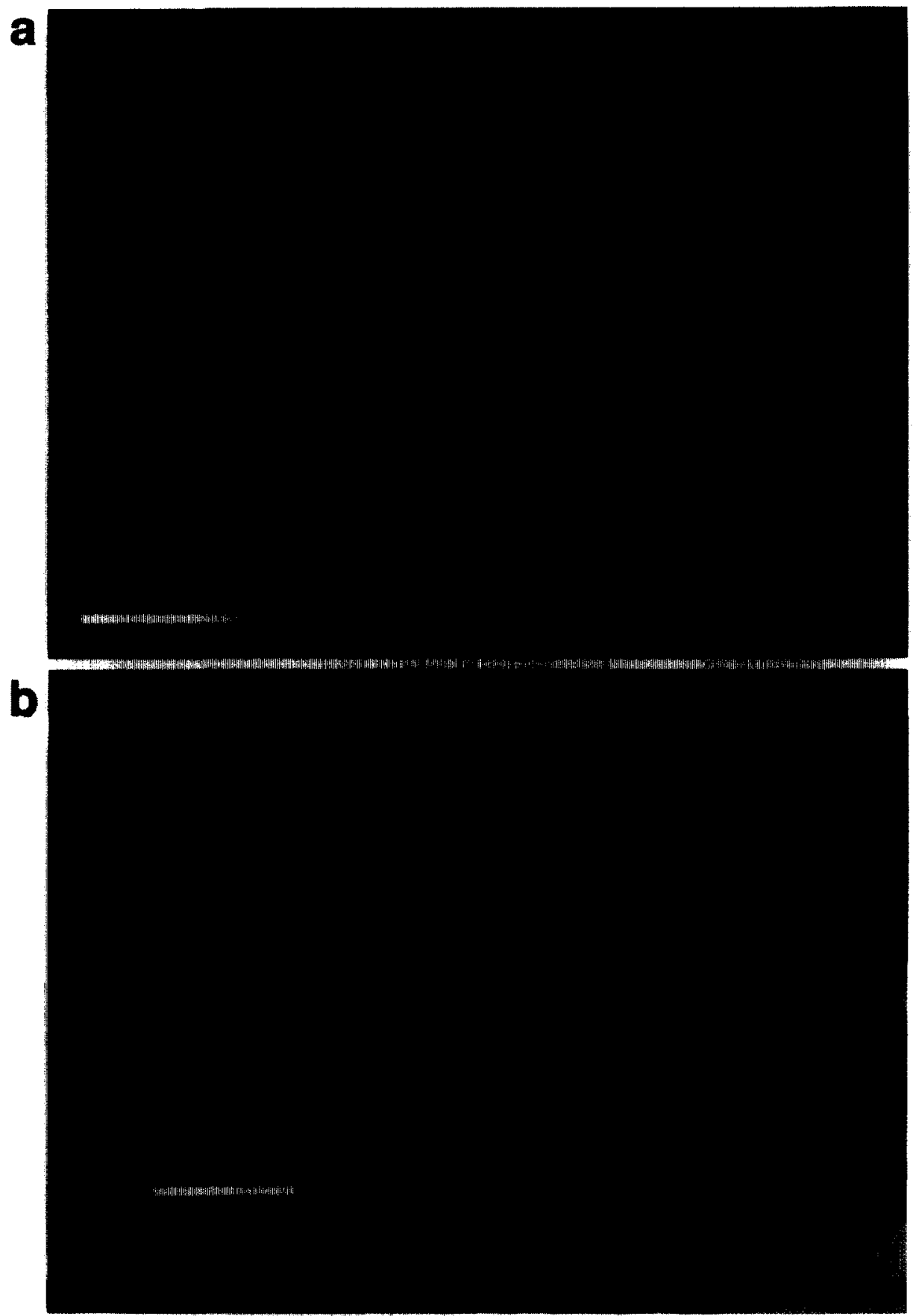

Fig. 1. (a) A dense population of stauromedusan sycphozoans clustered on bare basalt around a small fissure from which cloudy, shimmering water was emanating at a deep-sea hydrothermal vent along the crest of the East Pacific Rise (Lat. 20 50.304'N; Long. $109^{\circ} 05.422^{\prime} \mathrm{W}$ ) at a depth of $2605 \mathrm{~m}$. Scale bar, $10 \mathrm{~cm}$. (b) Higher magnification image depicting individual polyps within the population. Scale bar, $3 \mathrm{~cm}$. Prints produced from $8 \mathrm{~mm}$ video images taken using the deep-diving submersible $A$ luin. 


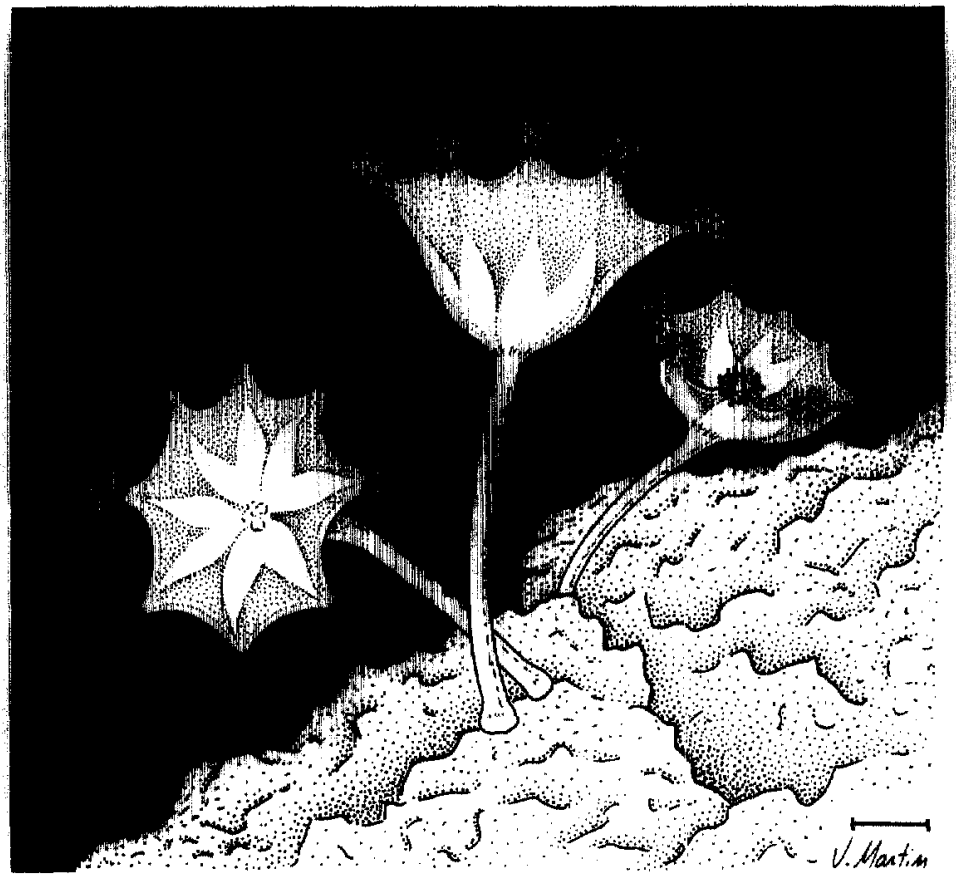

Fig. 2. Composite drawing prepared from examination of video footage taken of the dense population of stauromedusan scyphozoans depicted in Fig. 1. Note the four paired gonads, the broad concave shape of the subumbrella, and the arrangement of 8 adradial lobes, each tipped with a cluster of short capitate tentacles, all of which suggest a close affinity with previously described species of the genus Lucernaria. Scale, $1 \mathrm{~cm}$. 
large size for stauromedusae). Several distinct morphological characteristics, such as the lack of rhopalioids, broad concave shape of the subumbrella, paired gonads, and the arrangement of eight adradial lobes, each tipped with a cluster of short capitate tentacles, suggest a close affinity with previously described species of the genus Lucernaria (Fig. 2).

We did not encounter the stauromedusan population until the end of a very long dive and, due to power constraints, we were unable to sample organisms or obtain temperature measurements at the vent site. Detailed video and $35 \mathrm{~mm}$ photographic imaging within several meters of the active hydrothermal venting in the area revealed a few galatheid (Munidopsis subsquamosa) and bythograeid (Bythograea thermydron) crabs and occasional anemones (Cyananthea sp.) as the only other vent-associated megafauna within the region and small, swimming crustaceans (probably amphipods), which may represent one of the primary food sources of the Stauromedusae. Other typical vent-associated mega- and macrofaunal organisms (Riftia pachyptila, Calyptogena magnifica, peltospirid and lepetodrilid limpets and coiled gastropods) were locally absent, despite being adundant at nearby vent sites less than a kilometer south of the present site. The absence of these organisms may reflect unusual chemical characteristics of the venting fluids or predation by Stauromedusae on the early life history stages of vent-endemic species.

It has been suggested that certain vent-endemic species may be Paleozoic or Mesozoic relics (Newman, 1985). The cnidarians are considered primitive organisms, and the Stauromedusae have been viewed as close to the ancestral scyphozoan stem form (Hyman, 1940; Thiel, 1966; Eckelbarger and Larson, 1993). Stauromedusae belong to a scyphozoan order characterized by unciliated planulae and are thought to have a highly restricted dispersal capability. While morphological similarities exist between these Stauromedusae and shallow-water species belonging to the genus Lucernaria, taxonomic placement awaits subsequent collection of the organism from the site. Despite the present taxonomic uncertainty, the presence of these organisms at a deep-sea hydrothermal vent site raises many intriguing questions concerning: (1) their biogeography and mechanisms of dispersal between discrete deep-sea hydrothermal systems; and (2) evolution of the Cnidaria, which has been termed one of the "essential phyla" in "the discussion on the origin of metazoan phylogeny" (Thiel, 1966). Given the fact that the species is one within a class (Scyphozoa) that thus far has not been reported from hydrothermal vents or other reducing environments, collections and further ecological and physiological studies of these highly unusual deep-sea inhabitants at this unique hydrothermal site are clearly warranted.

\section{Acknowledgements}

We thank Ronald J. Larson and Michael R. Black for critical reviews of the manuscript, Violaine Martin for the drafting of Fig. 2, the crews of both the $R / V$ Atlantis $I I$ and $D S V$ Alvin for invaluable technical assistance which made possible the discovery and documentation of the described vent community, and Robert $R$. Hessler for tremendous inspiration over the years and for constantly reminding the 
senior author about the important things in life. This paper is Contribution No. 97-01 of the Institute of Marine and Coastal Sciences, Rutgers University and New Jersey Agricultural Experiment Station Publication No. D-32402-1-97, supported by state funds, National Science Foundation (NSF) grants OCE-89-17311, OCE-92-17026, OCE-93-02205, OCE-95-29819, and OCE-96-33131, and National Institute of Health (NIH) grant PHSTW00735-01.

\section{References}

Barnes, R.D., 1987. Invertebrate Zoology. Saunders College/Holt, Rinehart and Winston, New York, $893 \mathrm{pp}$.

Desbruyeres, D., Alayse-Dante, A.-M., Ohta, S., and the Scientific Parties of BIOLAU and STARMER Cruises, 1994. Deep-sea hydrothermal communities in Southwestern Pacific back-arc basins (the North Fiji and Lau Basins): Composition, microdistribution and food web. Marine Geology 116, 227-242.

Eckelbarger, K.J., Larson, R.J., 1993. Ultrastructural study of the ovary of the sessile scyphozoan Haliclystus octoradiatus (Cnidaria: Stauromedusae). Journal of Morphology $218,225-236$

Grassle, J.F., 1986. The ecology of deep-sea hydrothermal vent communities. Advances in Marine Biology 23, 301-362.

Hessler, R.R., Lonsdale, P.F., 1991. Biogeography of Mariana trough hydrothermal vent communities. Deep-Sea Research 38, 185-199.

Hyman, L.H., 1940. Protozoa Through Ctenophora. In: The Invertebrates, vol. 1. McGrawHill, New York, $726 \mathrm{pp}$.

Lutz, R.A., Kennish, M.J., 1993. Ecology of deep-sea hydrothermal vent communities: a review. Reviews of Geophysics 31, 211-242.

Naumov, D.W., 1961. Scyphomedusae of the seas of the USSR. Keys to the Fauna of the USSR, vol. 75, (Zoological Institute, Academy of Sciences, Moscow) pp. 1-97.

Newman, W.A., 1985. The abyssal hydrothermal vent invertebrate fauna, a glimpse of antiquity? In: Jones, M.L. (Ed.), The Hydrothermal Vents of the Eastern Pacific: An Overview. Bulletin of the Biological Society of Washington, Washington DC, vol. 6, pp. 231-242.

Otto, J., 1976. Early development and planula movement in Haliclystus. In: Mackie, G.O. (Ed.), Coelenterate Ecology and Behavior, Plenum Press, New York, pp. 319-329.

Otto, J., 1978. The settlement of Halicylystus planulae. In: Chia, F.S., Rice, M.E. (Eds.), Settlement and Metamorphosis of Marine Invertebrate Larvae. Elsevier, New York, pp. 13-20.

Rona, P.A., Klinkhammer, G., Nelson, T.A., Trefry, J.H., Elderfield, H., 1986. Black smokers, massive sulphides, and vent biota at the Mid-Atlantic Ridge. Nature 321, 33 37.

Thiel, H., 1966. The evolution of scyphozoa: a review. In: Rees. W.J. (Ed.), The Cnidaria and Their Evolution. Academic Press, New York, pp. 77-117.

Tunnicliffe, V., 1991. The biology of hydrothermal vents: ecology and evolution. Oceanography and Marine Biology Annual Reviews 29, 319-407.

Van Dover, C.L., 1990. Biogeography of hydrothermal vent communities along seafloor spreading centers. Trends in Ecology and Evolution 5, 238-243. 